\title{
In vitro cytotoxicity of ethanolic extract of the leaf of Calotropis gigantea from Ie Jue Geothermal Area, Aceh-Indonesia, and its mouthwash formulation against dental pulp cells
}

\author{
Diana Setya Ningsih ${ }^{1}$, Rinaldi Idroes ${ }^{2 *}$ (D), Boy M. Bachtiar ${ }^{3}$, Khairan Khairan², Trina Ekawati Tallei ${ }^{4}$, Muslem Muslem \\ ${ }^{1}$ Graduate School of Mathematics and Applied Sciences, Universitas Syiah Kuala, Banda Aceh, Indonesia. \\ ${ }^{2}$ Department of Pharmacy, Faculty of Mathematics and Natural Sciences, Universitas Syiah Kuala, Banda Aceh, Indonesia. \\ ${ }^{3}$ Department of Oral Biology, Faculty of Dentistry, Universitas Indonesia, Jakarta, Indonesia. \\ ${ }^{4}$ Department of Biology, Faculty of Mathematics and Natural Sciences, Sam Ratulangi University, Manado, Indonesia. \\ ${ }^{5}$ Department of Chemistry, Faculty of Science and Technology, Universitas Islam Negeri Ar-Raniry, Banda Aceh, Indonesia.
}

\begin{tabular}{l}
\hline ARTICLE INFO \\
\hline Received on: 29/05/2021 \\
Accepted on: 10/09/2021 \\
Available Online: 05/02/2022 \\
\\
\hline Key words: \\
Calotropis gigantea extract, \\
geothermal area, mouthwash \\
formulation, cytotoxicity, \\
antibacterial.
\end{tabular}

\section{INTRODUCTION}

Aceh has several geothermal sites which are contributed by volcanic activities from Jaboi (Idroes et al., 2021b), Seulawah Agam (Marwan et al., 2019a, 2019b), and Burni Geureudong (Dharma et al., 2021; Marwan et al., 2021; Putri et al., 2019). This condition has an effect on the biodiversity that exists in the

\footnotetext{
*Corresponding Author

Rinaldi Idroes, Department of Pharmacy, Faculty of Mathematics and Natural Sciences, Universitas Syiah Kuala, Banda Aceh, Indonesia. E-mail: rinaldi.idroes@unsyiah.ac.id
}

\begin{abstract}
The ethanolic Calotropis gigantea leaf extract (ECGLE) from Ie Jue geothermal area, Aceh-Indonesia, and ECGLEranging from 0 to $25 \%$ of ECGLE. Both the extract and formulation were evaluated for antibacterial and in vitro cytotoxic activity in order to determine their potential medicinal value in the oral cavity. Antibacterial tests were carried a mix of both Gram-negative and Gram-positive bacteria (P. gingivalis $+S$. moorei). The cytotoxic activity was evaluated against human dental pulp primary cells (hDPPC) by calorimetric assay using 3-(4,5-dimethylthiazol-2yl)-2,5-diphenyltetrazolium bromide. All formulations passed the stability test with a $\mathrm{pH}$ of 5.35-5.92. Antibacterial activity testing revealed that the higher the ECGLE concentration, the more effective it is against bacteria. In comparison inhibitory concentration (MIC) value and \% inhibition of formulation-3 against P. gingivalis, S. moorei, and a mix of both bacteria were $0.089,0.075$, and $0.083 \mu \mathrm{g} / \mathrm{ml}$ and $88.924 \%, 90.691 \%$, and $89.72 \%$, respectively. The cytotoxicity activities $\left(\mathrm{IC}_{50}\right)$ for both ECGLE and a formulation containing ECGLE were 6.44 and $0.27 \mathrm{gr} / \mathrm{ml}$, respectively. The ability of cells to undergo apoptosis showed a strong correlation between cell viability and the ECGLE extract $\left(R^{2}=\right.$ $0.973)$ as well as ECGLE-based mouthwash formulation $\left(R^{2}=0.897\right)$. The greater the concentration of ECGLE extract or ECGLE-based mouthwash formulation, the lower the viability of hDPPCs, but the greater the antibacterial activity.
\end{abstract}

area (Idroes et al., 2016, 2017). Ie Jue is one of the geothermal manifestations in Seulawah Agam volcano (Idroes et al., 2019a, 2019c; Marwan et al., 2021). This manifestation has higher acidity and temperature than the others (Ie Seu'eum and Ie Broek) (Idroes et al., 2018, 2019b). This situation contributes to plants' characteristics with thermal and dry resistances that grow massively in the Ie Jue area. The extreme environment forces the synthesis metabolism to produce more secondary metabolites (Nuraskin et al., 2019, 2020). As a result, the plants that grow there may have medicinal properties, such as antioxidants (Cane et al., 2020; Suhartono et al., 2019), antimicrobial (Estevam et al., 2015; Ningsih et al., 2019), antibacterial (Nuraskin et al., 
2019, 2020; Rahmad et al., 2019; Tallei et al., 2020), antiviral (Khairan et al., 2021; Tallei et al., 2020, 2021a, 2021b; Tumilaar et al., 2021), antibiofilm (Pratiwi et al., 2015), and wound healing (Earlia et al., 2019a, 2019b).

One of the plants which are plenteous in the Ie Jue area is Calotropis gigantea. This plant is categorized as a weed that can thrive in unfertilized soil, geothermal area, near the coastal area, or places with direct sunlight exposure (Tezara et al., 2011). Calotropis gigantea, from the family Asclepiadaceae, is a unique plant from Southeast Asia. This plant is also known as giant milkweed/swallow-wort (English), erukku (Indian), remiga (Malaysian), and widuri or biduri (Indonesian), and in Aceh, it is known as rubeek (Sampath Kumar et al., 2015).

Calotropis gigantea is commonly used as a therapy for various diseases, such as antibacterial, anticancer, antitumor, antioxidant, and wound healing (Bairagi et al., 2018; Deshmukh et al., 2009; Idroes et al., 2021; Jacinto et al., 2011; Kar et al., 2018; Seniya et al., 2011; Singh et al., 2010). All parts of this plant can be used as herbal medicine, including its leaf (Bairagi et al., 2018). Calotropis gigantea leaf has been reported to contain several compounds, such as flavonoids, alkaloids, saponins, triterpenoids, tannins, and polyphenols. The use of this plant in traditional therapy tends to disregard the concentration and side effects which may be caused by the compound content in the leaves. Usually, the medicinal plant has biological and chemical activities that can influence the cell of an organism, such as cytotoxic activity.

Based on Nguyen et al. (2017) and Jacinto et al. (2011), the methanol and dichloromethane extracts of $C$. gigantea leaf have high cytotoxicity against human pancreatic cancer cell lines, colon carcinoma, lung non-small-cell adenocarcinoma, and liver hepatocarcinoma (Bairagi et al., 2018; Deshmukh et al., 2009; Idroes et al., 2021; Jacinto et al., 2011; Kar et al., 2018; Nguyen et al., 2017; Seniya et al., 2011; Singh et al., 2010). However, there is no investigation yet concerning the cytotoxic activities of this plant extract against the oral cells such as human dental pulp primary cells (hDPPCs). The exposure of $C$. gigantea leaves extract or its formulation has the potential to produce positive or negative effects against the hDPPCs, which can be investigated by in vitro cytotoxicity test.

Niles et al. (2009) stated that the in vitro cytotoxicity simplified the threshold test of drug safety and validated the target for the basis of drug modification. Furthermore, cytotoxicity studies play a role in safeguarding the safety, reducing the production cost, observing the reaction of the cellular membrane, and penetration ability of the drug to the body, including the oral cavity (Bácskay et al., 2018; Niles et al., 2009). Investigation of cytotoxic activities of $C$. gigantea leaves, utilized for oral cavity, is still limited, especially in the form of herbal mouthwash formulation. Hence, this research aimed to identify the antibacterial and cytotoxic activities of the ethanolic $C$. gigantea leaf extract (ECGLE) and its formulation in the form of mouthwash against the hDPPCs.

\section{MATERIALS AND METHODS}

\section{Materials and apparatus}

This research was a laboratory experiment with a posttestonly control group design. It was conducted in the Laboratory of Oral Biology, Faculty of Dentistry, Universitas Indonesia. Calotropis gigantea leaves were collected from Ie Jue geothermal area, Aceh Besar Regency (location coordinate: 5030'24"N $\left.95^{\circ} 37^{\prime} 46^{\prime \prime} \mathrm{E}\right)$, Aceh-Indonesia. Leaf samples were extracted with ethanol and their cytotoxicity against hDPPCs was determined. The pulp cell was the sixth generation maintained by Oral Biology Laboratory, Faculty of Dentistry, Universitas Indonesia.

\section{Preparation of ECGLE}

The leaves of $C$. gigantea were washed and dried for 14 days at room temperature. The dry leaves were cut and ground using a crusher to produce a simplicia. One part of dried simplicia was added to a macerator, followed by the addition of 10 parts of ethanol $96 \%$, rinsed for 6 hours, and allowed to rest for 18 hours. The resulting macerate was precipitated and filtered. The filtrate was evaporated using a rotary evaporator to obtain a concentrated ECGLE.

\section{Preparation of the ECGLE-contained formulation}

The procedure for preparing the mouthwash formulation was modified from a previously published study (de Paula et al., 2014). The composition of this formulation can be seen in Table 1. All materials were dissolved in distilled water up to $100 \mathrm{ml}$. Each formulation is distinguished by the amount of ECGLE added to the mouthwash formulation.

\section{Quality control tests of the ECGLE-based mouthwash formulation}

The stability test of the ECGLE-based mouthwash formulation was carried out using the shock thermal method by combining high and low temperatures during storage. The formulated mouthwash was put into a heat-resistant container and then exposed to high temperature $\left(60^{\circ} \mathrm{C}\right)$ for 1 day. Furthermore, the mouthwash was exposed to low temperatures for 1 day $\left(-20^{\circ} \mathrm{C}\right)$. This process was carried out continuously for 6 days $(3 \times$ cycles) and then transferred to room temperature. During these processes, physical conditions were observed, especially changes in consistency, color, smell, and appearance (Ahmad et al., 2018).

\section{Bacterial strains and culture conditions}

Porhyromonas gingivalis ATCC 33277 and Solobacterium moorei ATTC 22971 strains were used in this research. Bacteria were spread separately on an agar brain heart infusion medium (BHI-Himedia Laboratories, India) and incubated for 24 hours under a microaerophilic atmosphere $(10 \%$ $\mathrm{H}_{2}: 10 \% \mathrm{CO}_{2}: 80 \% \mathrm{~N}_{2}$ ).

\section{Antibacterial activity test}

Antibacterial tests were carried out using the microdilution method. $100 \mu \mathrm{l}$ of ECGLE extracts $(25 \%, 12.5 \%, 6.25 \%, 3.13 \%$, and $1.56 \%$ ) and ECGLE-based mouthwash formulation (F0, F1, F2, and F3) were added to the culture plate 96 well (microplate). Then $100 \mu \mathrm{l}$ of bacteria (P. gingivalis, $S$. moorei, and a mix of both $P$. gingivalis and $S$. moorei bacteria, which have been diluted previously) was added. The microplate was closed and put in an anaerobic jar at $37^{\circ} \mathrm{C}$ for 24 hours $\left(10 \% \mathrm{H}_{2}: 10 \% \mathrm{CO}_{2}: 80 \% \mathrm{~N}_{2}\right)$. After incubation, the microplates were removed and read using a microplate reader (M965+, Metertech Inc., Taipei, Taiwan) at 600 $\mathrm{nm}$. The minimum inhibitory concentration (MIC) was defined as the lowest concentration that completely inhibits the growth of the microorganism or no visible microbial growth observed within 
Table 1. Formulation composition with a variation of ECGLE concentration.

\begin{tabular}{ccccc}
\hline & \multicolumn{5}{c}{ Formulation (gr) } \\
\hline Composition & Formulation 0 & Formulation 1 & Formulation 2 & Formulation 3 \\
\hline C. gigantea extract & - & 0.1 & 0.2 & 0.3 \\
Sodium benzoate & 0.1 & 0.1 & 0.1 & 0.1 \\
Saccharin & 0.1 & 0.1 & 0.1 & 0.1 \\
Propylene & 15 & 15 & 15 & 15 \\
Mint aroma & 0.5 & 0.5 & 0.5 & 0.5 \\
Sodium fluoride & 0.05 & 0.05 & $100 \mathrm{ml}$ & 0.05 \\
Distilled water & $100 \mathrm{ml}$ & $100 \mathrm{ml}$ & & $100 \mathrm{ml}$ \\
\hline
\end{tabular}

the plate. The percentage of inhibition of the extract/formulation against the tested bacteria was calculated by the following formula (Saquib et al., 2019):

$$
\% \text { inhibition }=\frac{\text { Abs. Control }- \text { Abs. sample }}{\text { Abs. Control }} \times 100
$$

\section{Cell culture}

Preparation of alpha minimum essential medium (MEM)

Alpha MEM was prepared in a sterile condition by dissolving fetal bovine serum $10 \%$ and AA $1 \%$ into a $50 \mathrm{ml}$ volumetric flask. The medium solution was filtered using a $0.2 \mu \mathrm{m}$ syringe filter (Laredo-Naranjo et al., 2016).

\section{Cell inoculation/growing}

Alpha MEM, which had previously been prepared, was taken up to $2 \mathrm{ml}$, diluted with hDPPCs, and added to a $15 \mathrm{ml}$ Falcon tube. The solution was centrifuged for 5 minutes at 2,000 rpm. The supernatant was removed before adding $1 \mathrm{ml}$ new MEM. It was stirred and removed into a $25 \mathrm{~cm}^{2}$ flask, followed by the addition of another $4 \mathrm{ml}$ MEM. The medium containing the cells was incubated at $37^{\circ} \mathrm{C}$ with $5 \% \mathrm{CO}_{2}$. The medium was replaced every 2 days until it reached $70 \%-80 \%$ confluence (Naz et al., 2019).

\section{Cell harvesting, calculation, and seeding}

The MEM was removed from the flask after the incubation. Three $\mathrm{ml}$ of PBS was added to the flask, then discharged, and added with $3 \mathrm{ml} 0.25 \%$ Trypsin ethylenediaminetetraacetic solution, followed by 5 minutes incubation. An inverted microscope (Carl Zeiss type Axiovert $40 \mathrm{CFL}$ ) was used to ensure that all cells were detached from the flask surface. The cell suspension was poured into $15 \mathrm{ml}$ Falcon tube and added with MEM medium to reach $3 \mathrm{ml}$. The procedure was followed by a 5-minutes centrifugation at 2,000 rpm at room temperature. Afterward, the supernatant was discharged and $1 \mathrm{ml}$ of new MEM medium was added to the tube. The cell suspension was then diluted by a factor of 10 . A total of $10 \mu \mathrm{l}$ of suspension was taken, homogenized, and dropped dropwise onto a hemocytometer for cell calculation using the following equation:

\author{
Total cell $=\frac{\begin{array}{c}\text { number of cell in } \\ \text { hemocytometer }\end{array}}{\begin{array}{c}\text { number of cell } \\ \text { counted }\end{array}} \times$ dilution factor $\times 10^{4}($ coef $)$
}

After that, the cell suspension was dripped into a 96-well plate based on the calculation. The plate was reincubated at $37^{\circ} \mathrm{C}$ with 5\% $\mathrm{CO}_{2}$ for 72 hours (Naz et al., 2019).

Exposure of the sample to cells

Ethanolic extract of $C$. gigantea leaves $(30 \mu \mathrm{l})$ was added to a 96-well plate containing cells after the medium had been replaced with $70 \mu \mathrm{l}$ new MEM. The microplate was incubated for 24 hours at $37^{\circ} \mathrm{C}$ with $5 \% \mathrm{CO}_{2}$. The microscope observation was carried out after 24 hours incubation with $10 \times$ magnification. The same procedure was applied to study the mouthwash formulation (Naz et al., 2019).

\section{Determination of cytotoxicity using MTT}

After the medium was renewed with $100 \mu \mathrm{l}$ MEM, the microplate was added with $50 \mu 1$ 3-(4,5-dimethylthiazol-2-yl)-2,5diphenyltetrazolium bromide (MTT) solution and incubated for 3 hours at $37^{\circ} \mathrm{C}$ with $5 \% \mathrm{CO}_{2}$. Acidified isopropanol $(100 \mu \mathrm{l})$ was added and the microplate was incubated on the shaker at room temperature for 1 hour. The absorbance was measured using Elisa Reader (Metertech type Accu Reader +) at $600 \mathrm{~nm}$, where the cell viability was calculated based on the following formulation (Tabari et al., 2017):

$$
\% \text { viability cells }=\frac{\left(\mathrm{abs}_{\text {sample }}-\mathrm{abs}_{\mathrm{blank}}\right)}{\left(\mathrm{abs}_{\text {control }}-\mathrm{abs}_{\mathrm{blank}}\right)} \times 100 \%
$$

\section{Morphological analysis of hDPPC}

Cell morphology was analyzed following ECGLE exposure to determine the changes in these cells. These include cell shrinkage, membrane decay, swelling, chromatin condensation, and the formation of apoptotic bodies. The observation was intended to predict the apoptosis mechanism. Meanwhile, vacuolation of the cytoplasm and the formation of double vesicle membranes containing organelles were observed in order to ascertain autophagic cell death (Bustillo et al., 2009).

\section{Results of the analysis}

The data were analyzed using Microsoft ${ }^{\circledR}$ Excel (Office SP, 2007). Data analysis included average, standard deviation 
of absorbance, linearity, correlation, $\mathrm{IC}_{50}$ of the ECGLE, and ECGLE-based mouthwash formulation on hDPPC viability.

\section{RESULTS}

The stability test revealed that all mouthwash formulations had the same organoleptic, viscosity, and temperature parameters at 0 and 6 days $(3 \times$ cycles). A slightly different result was shown by the formulation acidity. The increase in $\mathrm{pH}$ occurred with the increase in ECGLE concentration. The increase in $\mathrm{pH}$ also occurred between before the cycle ( 0 days) and after passing through three cycles ( 6 days). The $\mathrm{pH}$ before the cycle was lower compared to that after three cycles. An increase in $\mathrm{pH}$ (more alkaline) occurred at F3 (Table 2). However, the $\mathrm{pH}$ value of all formulations was still in the neutral range (5.35-5.92).

\section{Antibacterial activities}

The MIC activity from both ECGLE- and ECGLE-based mouthwash formulation showed that the smaller the concentration used, the lower the MIC resulted (Fig. 1A). The lowest MIC value was shown at a concentration of $1.56 \%$, where $P$. gingivalis had a lower MIC value of $0.059 \mathrm{mg} / \mathrm{ml}$ compared to other bacteria $(0.079 \mathrm{mg} / \mathrm{ml}$ for $S$. moorei and $0.055 \mathrm{mg} / \mathrm{ml}$ for a mix of both bacteria).

However, when compared to the ECGLE-based mouthwash formulation, the MICs were significantly lower (Fig. 1B) than ECGLE MIC (Fig. 1B). Overall, the resulting MIC value ranges were $0.089-0.094 \mathrm{mg} / \mathrm{ml}$ for $P$. gingivalis, $0.075-0.800$ $\mathrm{mg} / \mathrm{ml}$ for $S$. moorei, and $0.083-0.096 \mathrm{mg} / \mathrm{ml}$ for a mix of both bacteria (dual-species). ECGLE-based mouthwash formulation 3 had the lowest overall MIC values for each bacterium.

The small MIC value generated was inversely proportional to the percentage of inhibition produced. The smaller the MIC, the greater the percentage of inhibition. In ECGLE, the percentage of inhibition was much smaller than mouthwash ECGLE-based mouthwash formulation. The highest percentage of inhibition produced by ECGLE was $63.361 \%$ for $P$. gingivalis, $90.400 \pm 0.498$ for $S$. moorei, and $93.327 \pm 1.199$ for dual-species. Meanwhile, the percentage of mouthwash ECGLEbased mouthwash formulation inhibitors was $88.924 \pm 2.531(P$. gingivalis), $90.691 \pm 2.342$ (S. moorei), and $89.72 \pm 2.417$ (dualspecies). The results of statistical tests showed that there were significant differences in MIC and the percentage of inhibition produced in this study between ECGLE concentrations (Saquib et al., 2019).

\section{Value of $\mathrm{IC}_{50}$ using MTT assay}

The results indicated that the higher concentration of ECGLE used, the higher the absorbance obtained. It also revealed that the absorbance of ECGLE-based mouthwash formulation was higher than ECGLE (Table 1).

Table 1 exhibits that the higher concentration of ECGLE, the higher the number of living hDPPCs, or in other words, the cell viability increased with $R^{2}=0.973$ (Fig. 1). The value of $R^{2}$ is close to 1 , which indicated a significant positive correlation.

On the other hand, the determination of linear correlation obtained from that of ECGLE-based mouthwash formulation gave a value of $R^{2}=0.8968$ (Fig. 3). This value showed a strong correlation between the concentrations of each formulation with the cell viability percentage. The correlation was negative, in which if the formulation concentration is high, then the percentage of cell viability is low, or vice versa.

The linear equation indicated that the ECGLE had a greater $\mathrm{IC}_{50}(6.44 \mathrm{gr} / \mathrm{ml})$ in comparison with that of the ECGLEbased mouthwash formulation $(0.27 \mathrm{gr} / \mathrm{ml})$. From LINEST, the $R^{2}$ value generated from ECGLE or mouthwash formulation was close to 1 , allowing an assumption that the experimental values of $x$ and $y$ will not be significantly different from that of the theoretical values. Moreover, the slope reaches 0.8145 with an intersection on the $y$-axis at 1.2112. Meanwhile, the formulation had a slope of $R^{2}$ $=-58.668$ with an intersection on the $y$-axis at 17.055 (Table 4).

\section{Morphology of hDPPCs}

The changes on hDPPCs after the exposure with the ECGLE- and ECGLE-based mouthwash formulation were observed using an inverted microscope with $10 \times$ magnification (Figs. 4 and 5). Morphological observation of hDPPCs was as much important as investigating the cytotoxicity effect of ECGLE.

Cell morphology analysis revealed that ECGLE exposure resulted in visible bulges. This was due to the blebbing of the cells, indicating an initial phase of cell apoptosis mechanism (programmed cell death). It was marked by the cell image with bulges as indicated by $\rightarrow$ and the living cells indicated by $\rightarrow$. Additionally, the images suggested the presence of cell shrinkage,

Table 2. The stability test of mouthwash formulation contained ECGLE.

\begin{tabular}{|c|c|c|c|c|c|c|c|c|}
\hline \multirow{2}{*}{ Formulation test } & \multicolumn{2}{|c|}{ F0 (day) } & \multicolumn{2}{|c|}{ F1 (day) } & \multicolumn{2}{|c|}{ F2 (day) } & \multicolumn{2}{|c|}{ F3 (day) } \\
\hline & 0 & 6 & 0 & 6 & 0 & 6 & 0 & 6 \\
\hline \multicolumn{9}{|l|}{ 1. Organoleptic } \\
\hline a. Color & $\begin{array}{c}\text { Transparent, } \\
\text { green }\end{array}$ & $\begin{array}{c}\text { Transparent, } \\
\text { green }\end{array}$ & $\begin{array}{c}\text { Transparent, } \\
\text { green }\end{array}$ & $\begin{array}{c}\text { Transparent, } \\
\text { green }\end{array}$ & $\begin{array}{c}\text { Transparent, } \\
\text { green }\end{array}$ & $\begin{array}{c}\text { Transparent, } \\
\text { green }\end{array}$ & $\begin{array}{c}\text { Transparent, } \\
\text { green }\end{array}$ & $\begin{array}{c}\text { Transparent, } \\
\text { green }\end{array}$ \\
\hline b. Taste & Sweet & Sweet & Sweet & Sweet & Sweet & Sweet & Sweet & Sweet \\
\hline c. Smell & Unique & Unique & Unique & Unique & Unique & Unique & Unique & Unique \\
\hline 2. $\mathrm{pH}$ & 5.35 & 5.52 & 5,48 & 5,56 & 5,56 & 5,59 & 5.78 & 5.92 \\
\hline 3. Viscosity & $\mathrm{Nd}$ & $\mathrm{Nd}$ & $\mathrm{Nd}$ & $\mathrm{Nd}$ & $\mathrm{Nd}$ & $\mathrm{Nd}$ & $\mathrm{Nd}$ & $\mathrm{Nd}$ \\
\hline 4. Temperature & 25.8 & 25.8 & 25.8 & 25.8 & 25.8 & 25.8 & 25.8 & 25.8 \\
\hline
\end{tabular}

Nd: not detected. 

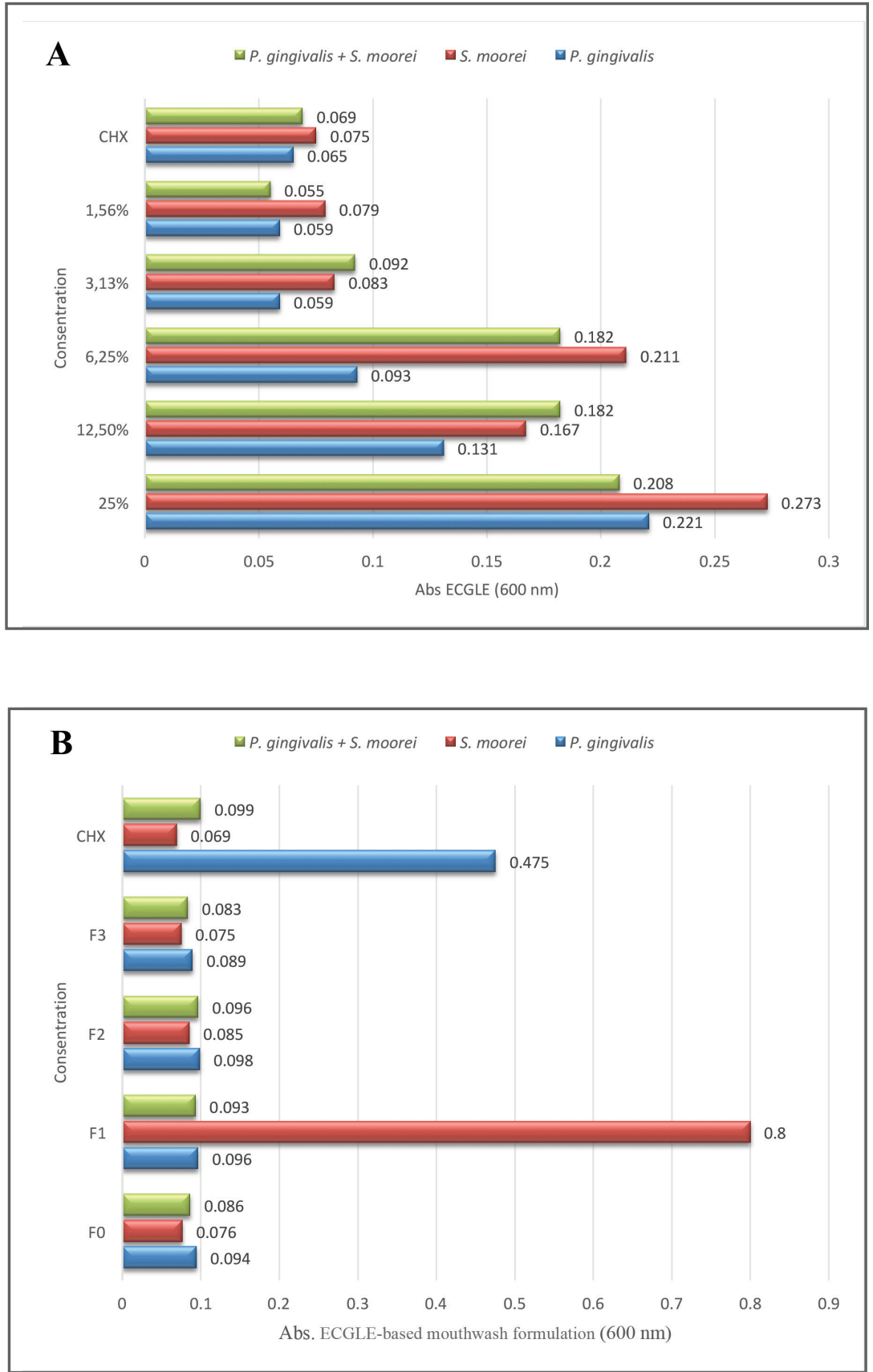

Figure 1. MIC activity at various concentrations: (A) EGCLE- and (B) ECGLE-based mouthwash formulation.

as indicated by a change in cell morphology from a basil to a spherical shape.

\section{DISCUSSION}

Stability tests conducted on the mouthwash formulation using organoleptic, temperature, viscosity, and $\mathrm{pH}$ parameters (Table 2) revealed that formulation 3 (F3) performed significantly better than the other formulations. However, overall the entire formulation was very non erosive to the teeth (Table 1). All formulations showed a $\mathrm{pH}$ in the range 5.35-5.92. This highly meets the recommended mouthwash $\mathrm{pH}$ standards according to ISO 16408-2015, that is, 3.0-10.5 (ISO, 2015), and the standards according to Collares, that is 4.11-7.0 (Collares et al., 2014). Based on this fact, it was ascertained that mouthwash ECGLEbased mouthwash formulation is safe to use ( $\mathrm{pH}$ 5.35-5.92).

Based on in vitro analysis, both ECGLE- and ECGLEbased mouthwash formulation showed excellent antibacterial activity. The lowest MIC to inhibit the growth of all tested bacteria occurred at the lowest ECGLE concentration (1.56\%) and ECGLE-based mouthwash formulation. It was assumed that the active substance produced was much greater so that the higher the extract concentration, the greater the ability to inhibit bacterial growth. Both extract and ECGLE-based mouthwash formulation were shown to be more able to inhibit Gram-positive 


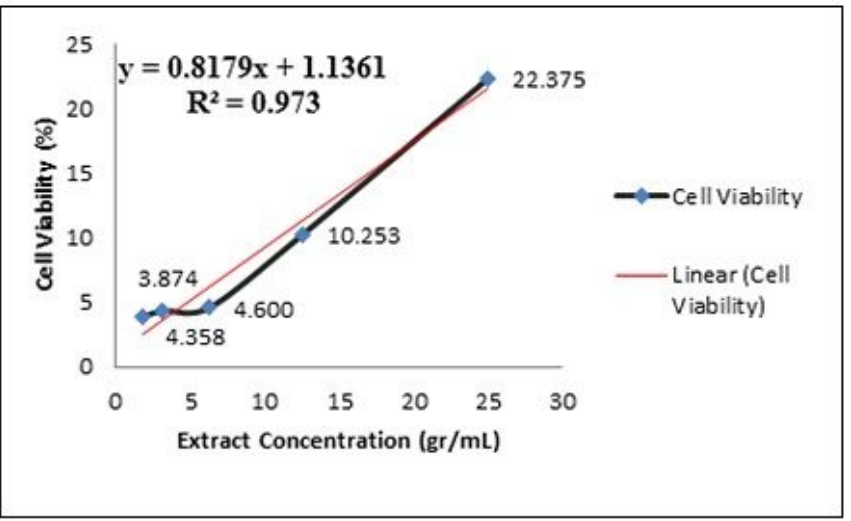

Figure 2. Cell viability and linearity of ethanolic extract of C. gigantea leaves.

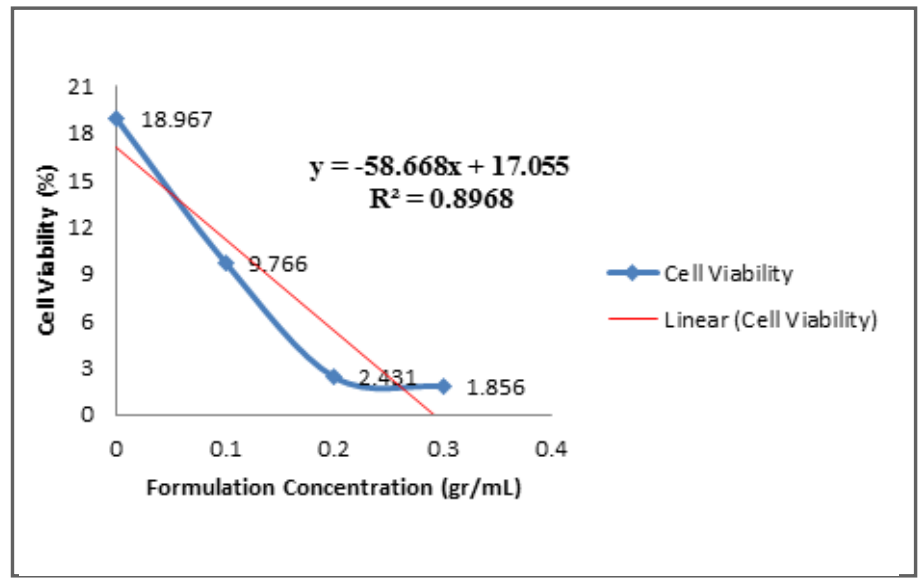

Figure 3. Cell viability and linearity of the ECGLE-based mouthwash formulation.

Table 3. The relationship between MIC and the \% inhibition occurred in the absorbances of ECGLE and formulation containing ECGLE.

\begin{tabular}{ccccccc}
\hline $\begin{array}{c}\text { Concentration/ } \\
\text { formulation }\end{array}$ & \multicolumn{2}{c}{ P. gingivalis } & \multicolumn{2}{c}{ S. moorei } & \multicolumn{2}{c}{ P. gingivalis + S. moorei } \\
\cline { 2 - 6 } & MIC (mg/ml) & \% inhibition & MIC (mg/ml) & \% inhibition & MIC (mg/ml) & \% inhibition \\
\hline & & & ECGLE & & \\
$25 \%$ & $0.221 \pm 0.110$ & $73.041 \pm 13.190$ & $0.273 \pm 0.031$ & $66.625 \pm 3.431$ & $0.208 \pm 0.113$ & $74.477 \pm 14.126$ \\
$12,50 \%$ & $0.131 \pm 0.050$ & $84.039 \pm 0.426$ & $0.167 \pm 0.035$ & $79.546 \pm 4.555$ & $0.182 \pm 0.297$ & $77.756 \pm 3.383$ \\
$6,25 \%$ & $0.093 \pm 0.016$ & $88.634 \pm 1.775$ & $0.211 \pm 0.026$ & $74.231 \pm 3.490$ & $0.182 \pm 0.021$ & $77.721 \pm 2.845$ \\
$3,13 \%$ & $0.059 \pm 0.005$ & $92.847 \pm 0.525$ & $0.083 \pm 0.003$ & $89.848 \pm 0.232$ & $0.092 \pm 0.008$ & $88.811 \pm 0826$. \\
$1.56 \%$ & $0.059 \pm 0.019$ & $92.830 \pm 2.416$ & $0.079 \pm 0.005$ & $90.400 \pm 0.498$ & $0.055 \pm 0.009$ & $93.327 \pm 1.199$ \\
CHX & $0.065 \pm 0.011$ & $92.056 \pm 1.295$ & $0.075 \pm 0.008$ & $90.831 \pm 0.935$ & $0.069 \pm 0.019$ & $91.573 \pm 2.327$ \\
F0 & & ECGLE-based mouthwash formulation & $90.684 \pm 1.919$ & $0.086 \pm 0.002$ & $89.231 \pm 2.965$ \\
F1 & $0.094 \pm 0.002$ & $88.304 \pm 2.687$ & $0.076 \pm 0.004$ & $90.07 \pm 2.498$ & $0.093 \pm 0.002$ & $88.552 \pm 2.625$ \\
F2 & $0.096 \pm 0.001$ & $88.062 \pm 3.173$ & $0.8 \pm 0.000$ & $89.479 \pm 2.902$ & $0.096 \pm 0.001$ & $88.107 \pm 2.822$ \\
F3 & $0.098 \pm 0.001$ & $87.909 \pm 2.957$ & $0.085 \pm 0.002$ & $90.691 \pm 2.342$ & $0.083 \pm 0.001$ & $89.72 \pm 2.417$ \\
CHX & $0.475 \pm 0.007$ & $94.093 \pm 1.570$ & $0.069 \pm 0.028$ & $91.928 \pm 1.284$ & $0.099 \pm 0.067$ & $88.823 \pm 5.262$ \\
\hline
\end{tabular}

The measurement was carried out in triplicate. 
Table 4. Absorbance of ECGLE- and ECGLE-based mouthwash formulation.

\begin{tabular}{cccc}
\hline ECGLE (\%) & $\boldsymbol{A}_{600} \mathbf{n m} \pm \mathbf{S D}$ & Mouthwash formulation & $\boldsymbol{A}_{600} \mathbf{n m} \pm \mathbf{S D}$ \\
\hline Control negative (medium) & $0.088 \pm 0.004$ & Control negative (medium) & $0.088 \pm 0.004$ \\
Control positive (cell) & $0.501 \pm 0.053$ & Control positive (cell) & $0.501 \pm 0.053$ \\
25 & $0.095 \pm 0.035$ & F0 & $0.078 \pm 0.022$ \\
12.5 & $0.042 \pm 0.022$ & F1 & $0.040 \pm 0.029$ \\
6.25 & $0.019 \pm 0.017$ & F2 & $0.010 \pm 0.002$ \\
3.13 & $0.018 \pm 0.004$ & F3 & $0.008 \pm 0.005$ \\
1.56 & $0.016 \pm 0.008$ & & \\
\hline
\end{tabular}

The measurement was carried out in triplicate.
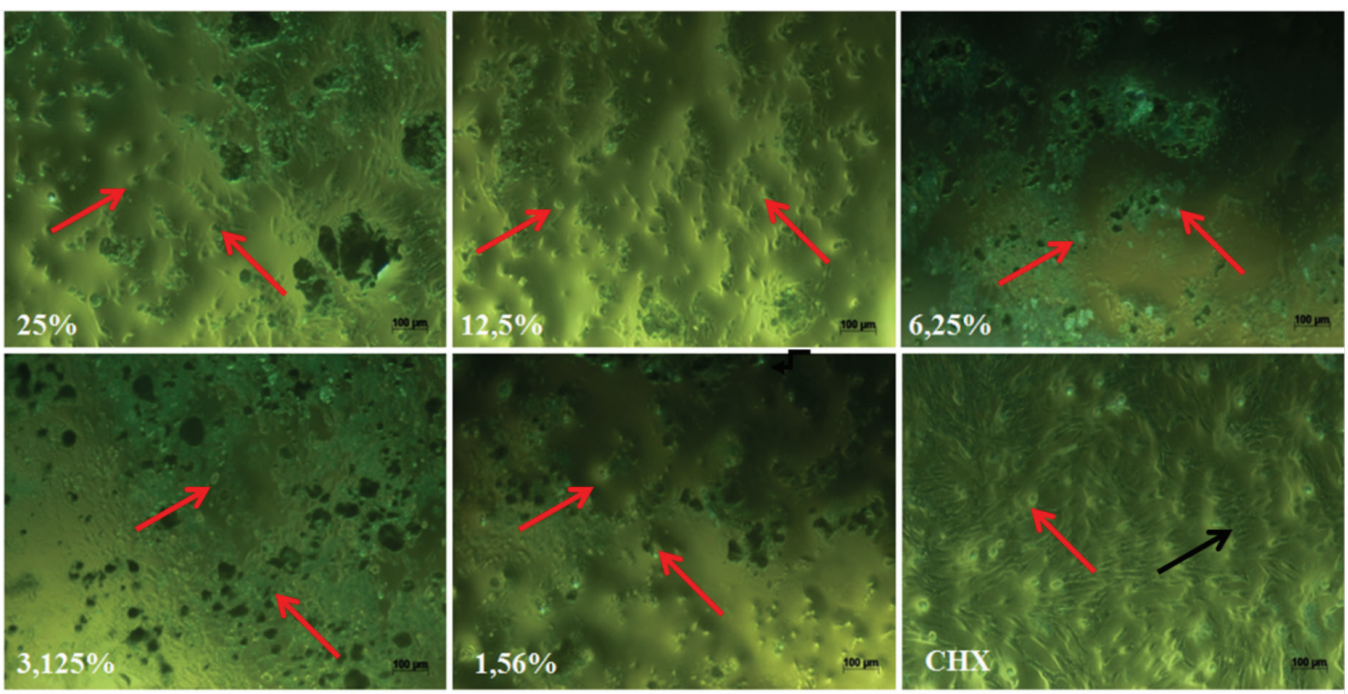

Figure 4. The effect of ECGLE addition on the morphology of hDPPCs. Living cells were indicated by the black arrow $(\rightarrow)$ and dead cells were indicated by the red arrow $(\rightarrow)$. The cells were observed using an inverted microscope with 10x magnification.

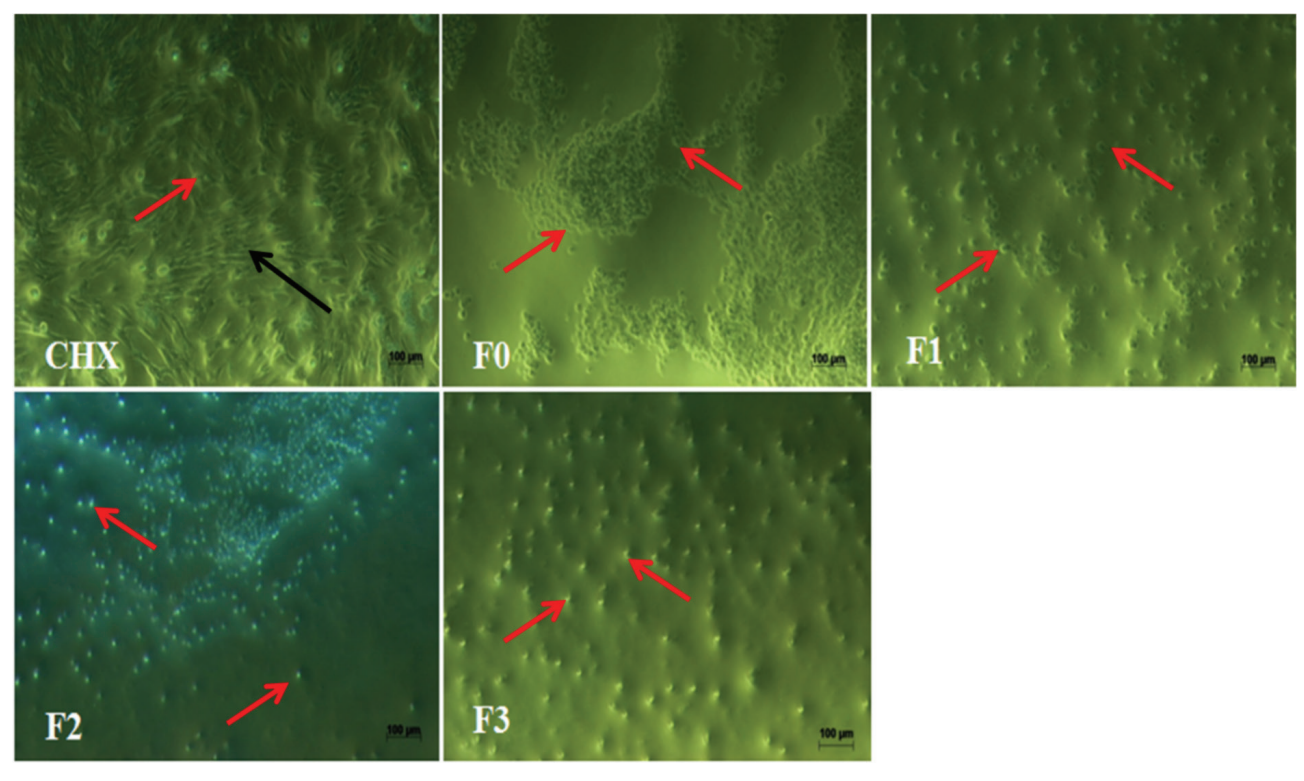

Figure 5. The effect of ECGLE-based mouthwash formulation addition on the morphology of hDPPCs. Living cells were indicated by the black arrow $(\rightarrow)$ and dead cells were indicated by the red arrow $(\rightarrow)$. The cells were observed using an inverted microscope with $10 x$ magnification. 


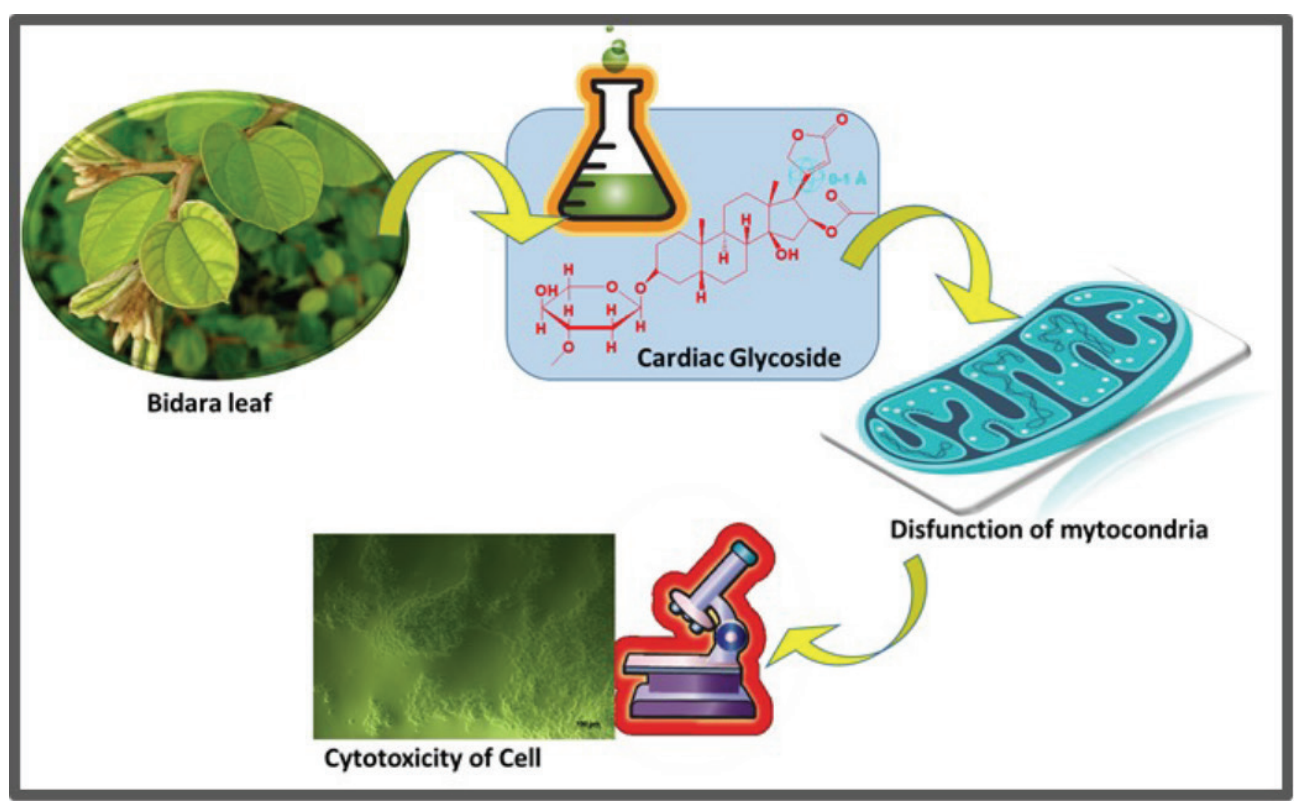

Figure 6. The graphic illustration of cardiac glycoside influence against hDPPCs cell.

than Gram-negative bacteria. This was thought to be caused by the lipopolysaccharide of Gram-positive bacteria being much thinner than that of Gram-negative bacteria. This finding was in line with Varposhti's research which stated that the thickness and composition of the bacterial membrane affected the bacteria inhibition ability (Varposhti et al., 2014).

The results of this study produced different cytotoxicity absorbance values, with ECGLE collected from the Ie Jue geothermal area yielding higher absorbance than the ECGLE-based mouthwash formulation (Table 4). It was based on the concentration difference between ECGLE- and ECGLE-containing formulation, with ECGLE having a higher concentration than ECGLE-based mouthwash formulation. The concentration/color intensity changed the produced absorbance from the real absorbance. It was in agreement with Lambert-Beer's law, which stated that there is a correlation between absorbance and sample concentration. Furthermore, the MTT method used in this research had a weakness. It was difficult to remove the formazan solution attached to the cell mitochondria, which affected the calculation results. This condition was in line with the report by Aslanturk (2018), where undissolved formazan used in the MTT method formed purple threads within the cells, which are difficult to be removed (Aslantürk, 2018). Research by Wang et al. (2010) suggested thorough evaluation on the method to study the in vitro cell proliferation which relied on the chemical properties of the studied plant supplemented (Wang et al., 2010).

These results on absorbance explained that the higher the sample concentration, the higher the absorbance (Table 4). Nonetheless, the contrary results were shown by the mouthwash formulation with a high ECGLE concentration. It was ascribed to the effect of interaction between the additives ingredients of the formulation. The addition of ingredients other than the ECGLE weakened or removed the ability of the mouthwash, affecting the absorbance from the mouthwash formulation.

In this research, the cytotoxicity activities of ECGLEand the ECGLE-based mouthwash formulation against hDPPCs were observable (Figs. 2 and 3). It was in line with Nguyen et al. (2017) and Jacinto et al. (2011) reports that $C$. gigantea leaf possessed high cytotoxicity (Bairagi et al., 2018; Deshmukh et al., 2009; Idroes et al., 2021a; Jacinto et al., 2011; Kar et al., 2018; Nguyen et al., 2017; Seniya et al., 2011; Singh et al., 2010). The high cytotoxicity was attributed to the presence of secondary metabolite contents of $C$. gigantea, such as cardiac glycoside. This compound was similar to calotropone, possessing cytotoxic activities against human chronic myelogenous leukemia cells and gastric cancer, based on the in vitro studies using the MTT method with $\mathrm{IC}_{50}$ of 9.7 and $6.7 \mu \mathrm{g} / \mathrm{ml}$, respectively (Wang et al., 2008).

Cardiac glycosides were known to be capable of inducing apoptosis by disrupting the homeostasis and inducing the mitochondrial pathway (Fig. 6) (Muti et al., 2016). This ability was also in line with the increasing concentration percentage, leading to the lower survival rate of the cell. The presence of the lysis process was suspected of causing necrosis on cells due to its cytotoxicity. The necrosis leads to cell swelling and cellular structure damage, stopping the metabolism, and then releasing out its components. This activity caused the cells to stop dividing and growing. In vitro cells with necrosis did not have sufficient time or energy to activate apoptosis and did not release apoptosis marker leading to the disruption in intracellular communication (Muti et al., 2016).

Low $\mathrm{IC}_{50}$ given by the formulation, in comparison with the crude extract, was associated with the different ingredients of each sample (Table 5). In the extract, the ingredients only consisted of the ECGLE with concentration variation and distilled water as the solvent. Meanwhile, in the formulation, the ingredients consisted of other ingredients, including sodium benzoate, saccharin, propylene glycol, disodium EDTA, sodium fluoride, and flavoring and coloring agents (Table 1). The additional ingredients were suspected to contribute to these higher cytotoxic activities, indicated by the low surviving cell viability. It was corroborated by Garland et al.'s report (1989) that saccharin reduced cell viability. Jeng et al. (1998) reported that sodium fluoride was toxic against the fibroblast cells from oral mucosa and commonly used to prevent caries (Jeng et al., 1998). Park 
Table 5. Calculation of $\mathrm{IC}_{50}$ from ECGLE- and ECGLE-based mouthwash formulation using linear regression.

\begin{tabular}{ccccc}
\hline Sample & & \multicolumn{2}{c}{ Value } & \\
\hline ECGLE & $\mathrm{IC}_{50}$ & $6.44 \mathrm{gr} / \mathrm{ml}$ & & Intercept \\
& Slope & 0.814544921 & 1.211190355 & SD Intercept \\
& Sdslope & 0.080912533 & 1.044061238 & Sdreg \\
& $R$-square & 0.971180289 & 1.542274121 & Intercept \\
& $\mathrm{IC}_{50}$ & $0.27 \mathrm{gr} / \mathrm{ml}$ & & SD Intercept \\
& Slope & -58.668 & 2.632458125 & Sdreg \\
\hline
\end{tabular}

et al. (2011) agreed that sodium benzoate possessed cytotoxic activity in a mammalian cell by increasing the intracellular $\mathrm{Ca}^{2+}$ concentration and mitochondrial transmembrane potential in a dose-dependent manner.

By observing the viability value of $<50 \%, C$. gigantea was concluded to possess high cytotoxicity. However, these results should be compared with other cytotoxicity tests such as LDH, BrdU, RT-CES, and agar overlay. Yet, Bácskay et al. (2018) suggested not to compare the cytotoxicity test using MTT assay with XTT test owing to the use of tetrazolium-based material, which is predicted to have a similar limitation with MTT test (Bácskay et al., 2018). Furthermore, plants with high cytotoxicity levels cannot always be used in the body, in which the exposed cell is not merely one cell but many other cells forming a colony. It then contributes to the higher cell resistance to be protected from the extract. ECGLE concentration used in further research should be lower to be capable of reducing the toxic effect of the extract.

The cytotoxicity effect was observed further in Figures 3 and 4, where the higher the extract concentration administered, the higher the cell death occurred. The presence of blebbing also indicates one of the cell death patterns (autophagia). Blebbing condition was more intense on the formulation exposure in comparison with that on the extract. Thus, it was concluded that the formulation has higher activities than the extract. These high activities were associated with the presence of other ingredients added in the mouthwash formulation. The formulation ingredient could also be capable of causing cell shrinkage, and the swells were observable on the surface, as seen in Figures 4 and 5. Ghabanci et al. (2013), in similar research, reported the comparison of three mouthwash having the cytotoxic effect on the cultured cell. The commercial formulation was also revealed to have high cytotoxicity (Ghabanchi et al., 2013). Research by Muller et al. (2017) suggested that chlorhexidine $0.05 \%$ had moderate cytotoxic activities, where chlorhexidine and cocamidopropyl betaine $0.2 \%$ showed strong cytotoxic and antibacterial activities (Sun et al., 2016).

The ECGLE- and ECGLE-based formulation were used as a mouthwash. The oral cavity contains many cells, not only single cells such as hDPPCs, but also other cells, which interact with each other to form cell layers. Logically, single cells tend to react on their own to fight external conditions so that it is thought to be easier to die than if several cells were combined together. This is in accordance with Muller's (2017) report, which described the ideal conditions that exist in the oral cavity (which contains several cells such as oral fibroblasts, epithelial cells, and immune system cells), which are thought to affect the ability of cells to survive external stimulation. Nevertheless, if we want to reduce the activity, it is suggested to use the extract in a lower concentration than that reported in this research. The most intriguing aspect of this research was the discovery that ECGLE extract/ECGLE-based mouthwash formulation with high cytotoxicity activity also has good antibacterial properties. This is believed to be because of the high antioxidant content, which inhibits antibacterial growth but is toxic to cells. The use of high antioxidants tends to lead to other cancer/degenerative treatments.

\section{CONCLUSION}

The ECGLE and ECGLE-based mouthwash formulation produced in this research had high cytotoxicity. As a result, additional research is required to establish a safety standard for its use on humans. The results revealed that the extract concentration of $C$. gigantea leaves determined the level of cytotoxicity on the dental pulp cell. In this research, it was observed that the ECGLEbased mouthwash formulation with $0.3 \mathrm{~g} / \mathrm{ml}$ extract of $C$. gigantea and $25 \%$ extract was far more cytotoxic against the hDPPC. The use of a lower concentration of active compounds of the $C$. gigantea extract was recommended to reduce the cytotoxicity effect on the hDPPC. ECGLE extract and ECGLE-based mouthwash formulation have shown in vitro growth inhibition of hDPPC. This was due to the induction of cell cycle arrest and apoptosis. However, future study is needed to understand the mechanisms of cytotoxicity of this plant extract.

\section{ACKNOWLEDGMENTS}

The authors appreciate the collaboration between Universitas Syiah Kuala, Banda Aceh, Indonesia, and Universitas Indonesia, Jakarta, Indonesia, who have contributed during the research and the making of this article. This research is funded by the Ministry of Education and Culture of the Republic of Indonesia under grant No 38/UN11.2.1/PT.01.03/DPRM/2020.

\section{AUTHOR CONTRIBUTIONS}

All authors made substantial contributions to conception and design, acquisition of data, or analysis and interpretation of data; took part in drafting the article or revising it critically for important intellectual content; agreed to submit to the current journal; gave final approval of the version to be published; and agree to be accountable for all aspects of the work. All the authors are eligible to be an author as per the international committee of medical journal editors (ICMJE) requirements/guidelines. 


\section{CONFLICTS OF INTEREST}

The authors report no financial or any other conflicts of interest in this work.

\section{ETHICAL APPROVALS}

This study does not involve experiments on animals or human subjects.

\section{PUBLISHER'S NOTE}

This journal remains neutral with regard to jurisdictional claims in published institutional affiliation.

\section{REFERENCES}

Ahmad S, Sinha S, Ojha S, Chadha H, Aggarwal B, Ajeet A, Jain S, Bhati M. Formulation and evaluation of antibacterial herbal mouthwash against oral disorders. Indo Glob J Pharm Sci, 2018; 08(02):37-40.

Aslantürk ÖS. In vitro cytotoxicity and cell viability assays: principles, advantages, and disadvantages. In: Larramendy ML (ed.). Genotoxicity - a predictable risk to our actual world. London, UK: InTech, 2018.

Bácskay I, Nemes D, Fenyvesi F, Váradi J, Vasvári G, Fehér P, Vecsernyés M, Ujhelyi Z. Role of cytotoxicity experiments in pharmaceutical development. In: Celik TA (ed.). Cytotoxicity. London, UK: InTech, 2018.

Bairagi S., Ghule P, Gilhotra R. Pharmacology of natural products: an recent approach on Calotropis gigantea and Calotropis procera. Ars Pharm, 2018; 59(1):37-44.

Bustillo S, Lucero H, Leiva L, Acosta O, Kier Joffé E, Gorodner J. Cytotoxicity and morphological analysis of cell death induced by Bothrops venoms from the northeast of Argentina. J Venom Anim Toxins Incl Trop Dis, 2009; 15(1):28-42.

Cane HPCA, Saidi N, Mustanir M, Darusman D, Idroes R. Evaluation of antibacterial and antioxidant activities of xanthone isolated from orophea corymbosa leaf. Rasayan J Chem, 2020; 13(4):2215-22.

Collares FM, Rostirolla FV, de Macêdo É de OD, Leitune VCB, Samuel SMW. Influence of mouthwashes on the physical properties of orthodontic acrylic resin. Brazilian J Oral Sci, 2014; 13(3):203-8.

Deshmukh PT, Fernandes J, Atul A, Toppo E. Wound healing activity of Calotropis gigantea root bark in rats. J Ethnopharmacol, 2009; 125(1):178-81.

Dharma DB, Rizal S, Umar M, Iskandar I, Devianti, Idroes R. Study on shallow borehole Water blowout genesis based on geo-chemical properties from affected dug wells water. IOP Conf Ser Earth Environ Sci, 2021; 644(1):012023.

Earlia N, Muslem M, Suhendra R, Amin M, Prakoeswa CRS, Khairan K, Idoroes R. GC/MS Analysis of fatty acids on pliek u oil and its pharmacological study by molecular docking to filaggrin as a drug candidate in atopic dermatitis treatment. Sci World J, 2019a; 2019:1-7.

Earlia N, Rahmad R, Amin M, Prakoeswa C, Khairan K, Idroes $R$. The potential effect of fatty acids from pliek $U$ on epidermal fatty acid binding protein: chromatography and bioinformatic studies. Sains Malaysiana, 2019b; 48(5):1019-24.

Estevam E, Griffin S, Nasim J, Zieliński D, Aszyk J, Osowicka M, Dawidowska N, Idroes R, Bartoszek A, Jacob C. Inspired by nature: the use of plant-derived substrate/enzyme combinations to generate antimicrobial activity in situ. Nat Prod Commun, 2015; 10(10):1733-8.

Garland EM, Parr JM, Williamson DS, Cohen SM. In vitro cytotoxicity of the sodium, potassium and calcium salts of saccharin, sodium ascorbate, sodium citrate and sodium chloride. Toxicol Vitro, 1989; 3(3):201-5.

Ghabanchi J, Moattari A, Darafshi R, Andisheh Tadbir A, Khorshidi H, Shakib M. Effects of three commercial mouth rinses on the cultured fibroblasts: an in vitro study. J Dent (Shiraz, Iran), 2013; 14(2):64-7.

Idroes GM, Tallei TE, Idroes R, Muslem, Riza M, Suhendrayatna The study of Calotropis Gigantea leaf metabolites from Ie Brouk geothermal area Lamteuba-Aceh Besar using molecular docking. IOP Conf Ser Earth Environ Sci, 2021a; 667(1):012072.

Idroes R, Khairan, Fakri F. Skrining Aktivitas Tumbuhan yang berpotensi sebagai bahan antimikroba di kawasan ie Jue (upflow geotermal Zone) Aceh besar. Banda Aceh, Indonesia: Unsyiah Press, pp 1-8, 2017.

Idroes R, Khairan, Fakri F, Zulfendi. Skrining Aktivitas Tumbuhan yang berpotensi sebagai bahan antimikroba di kawasan ie suum (outflow geotermal Zone) Aceh besar. 1st edition. Banda Aceh, Indonesia: Unsyiah Press, pp 1-9, 2016

Idroes Rinaldi, Marwan M, Yusuf M, Muslem M, Helwani Z. Geochemical Investigation on Jaboi Manifestation, Jaboi Volcano, Sabang, Indonesia. Int J GEOMATE [En ligne], 2021b; 20(82).

Idroes R, Yusuf M, Alatas M, Subhan, Lala A, Muhammad, Suhendra R, Idroes GM, Marwan. Geochemistry of Sulphate spring in the Ie Jue geothermal areas at Aceh Besar district, Indonesia. IOP Conf Ser Mater Sci Eng, 2019a; 523:012012.

Idroes R, Yusuf M, Alatas M, Subhan, Lala A, Muslem M, Suhendra R, Idroes GM, Suhendrayatna S, Marwan M, Riza M. Geochemistry of warm springs in the Ie Brôuk hydrothermal areas at Aceh Besar district. IOP Conf Ser Mater Sci Eng, 2019b; 523:012010.

Idroes R, Yusuf M, Saiful S, Alatas M, Subhan S, Lala A, Muslem M, Suhendra R, Idroes GM, Marwan M, Mahila TMI. Geochemistry exploration and geothermometry application in the North Zone of Seulawah Agam, Aceh Besar District, Indonesia. Energies, 2019c; 12(23):4442.

Idroes R, Yusuf M, Alatas M, Subhan, Lala A, Saiful S, Suhendra R, Idroes GM, Marwan M. Geochemistry of hot springs in the Ie Seu'um hydrothermal areas at Aceh Besar district, Indonesia. IOP Conf Ser Mater Sci Eng, 2018; 334:012002.

ISO. ISO 16408:2015. Dentistry — Oral care products - Oral rinses. European Committee for Standardization, Dublin, Ireland.

Jacinto SD, Chun EAC, Montuno AS, Shen C-C, Espineli DL, Ragasa CY. Cytotoxic Cardenolide and Sterols from Calotropis Gigantea Nat Prod Commun, 2011; 6(6):1934578X1100600.

Jeng JH, Hsieh CC, Lan WH, Chang MC, Lin SK, Hahn LJ, Kuo MY. Cytotoxicity of sodium fluoride on human oral mucosal fibroblasts and its mechanisms. Cell Biol Toxicol, 1998; 14(6):383-9.

Kar D, Kuanar A, Pattanaik PK. Antimicrobial activities of different parts of Calotropis gigantea: a naturally occurring prophylactic medicinal shrub. Iran J Sci Technol Trans A Sci, 2018; 42(3):1057-62.

Khairan K, Idroes R, Tumilaar SG, Tallei TE, Idroes GM, Rahmadhany F, Futri MU, Dinura NM, Mauliza S, Diana M, Maisarah P, Maulana A, Noviandy TR, Suhendra R, Muslem M, Earlia N. Molecular docking study of fatty acids from Pliek $\mathrm{U}$ oil in the inhibition of SARS-CoV-2 protein and enzymes. IOP Conf Ser Mater Sci Eng, 2021; 1087(1):012058.

Laredo-Naranjo MA, Carrillo-Gonzalez R, De La Garza-Ramos MA, Garza-Navarro MA, Torre-Martinez HHH, Del Angel-Mosqueda C, Mercado-Hernandez R, Carrillo-Fuentevilla R. Antimicrobial properties and dental pulp stem cell cytotoxicity using carboxymethyl cellulose-silver nanoparticles deposited on titanium plates. Acta Biomater Odontol Scand, 2016; 2(1):60-7.

Marwan M, Idroes R, Yanis M, Idroes GM, Syahriza. A low-cost UAV based application for identify and mapping a geothermal feature in Ie Jue Manifestation, Seulawah Volcano, Indonesia. Int J GEOMATE, 2021a; 20(80).

Marwan M, Noviandy TR, Maulana A, Suhendra R, Yusuf M, Lala A, Idroes GM, Muslem M, Mahmudi, Idroes R. Utilization of unmanned aerial vehicles in geothermal exploration: a review. IOP Conf Ser Mater Sci Eng, 2021b; 1087(1):012072.

Marwan M, Syukri M, Idroes R, Ismail N. Deep and shallow structures of geothermal Seulawah Agam based on electromagnetic and magnetic data. Int J GEOMATE, 2019a; 16(53):141-7.

Marwan M, Yanis M, Idroes R, Ismail N. 2D inversion and static shift Of MT And TEM data for imaging the geothermal resources of Seulawah Agam Volcano, Indonesia. Int J GEOMATE, 2019b; 17(62):173-80.

Müller HD, Eick S, Moritz A, Lussi A, Gruber R. Cytotoxicity and antimicrobial activity of oral rinses in vitro. Biomed Res Int, 2017; 2017. 
Muti R, Pramesti Griana T, Nurul Ula Q, Andhyarto Y. The effect of Calotropis gigantea leaves extract on fibrosarcoma growth and caspase 3 expression. Maulana Malik Ibrahim State Islamic University of Malang, Malang, Indonesia, 2016.

Naz S, Khan FR, Zohra RR, Lakhundi SS, Khan MS, Mohammed $\mathrm{N}$, et al. Isolation and culture of dental pulp stem cells from permanent and deciduous teeth. Pak J Med Sci, 2019; 35(4):997-1002.

Ningsih DS, Idroes R, Bachtiar BM, Khairan. The potential of five therapeutic medicinal herbs for dental treatment : a review. IOP Conf Ser Mater Sci Eng, 2019; 523(1):12009.

Niles AL, Moravec RA, Riss TL. In vitro viability and cytotoxicity testing and same-well multi-parametric combinations for high throughput screening. Curr Chem Genomics, 2009;3:33-41.

Nguyen KDH, Dang PH, Nguyen HX, Nguyen MTT, Awale S, Nguyen NT. Phytochemical and cytotoxic studies on the leaves of Calotropis gigantea. Bioorg Med Chem Lett, 2017; 27(13):2902-6.

Nuraskin Cut A., Marlina M, Idroes R, Soraya C, Djufri D. Antibacterial Activity Tests of N-hexane, Ethyl Acetate, and Methanol Leaves (Vitex) Extract (pinnata) against Streptococcus mutans. Open Access Maced J Med Sci, 2020a; 8(A):181-4.

Nuraskin Cut, Marlina M, Idroes R, Soraya C, Djufri D. Identification of secondary metabolite of laban leaf extract (Vitex pinnata 1) from geothermal areas and non-geothermal of agam mountains in Aceh Besar, Aceh province, Indonesia. Rasayan J Chem, 2020b; 13(1):18-23.

Nuraskin CA, Marlina M, Idroes R, Soraya C, Djufri D. Activities inhibition methanol extract Laban Leaf ( Vitex pinnata ) on growth of bacteria S. mutans Atcc 31987. IOP Conf Ser Mater Sci Eng, 2019a; 523(1):012008.

Nuraskin Cut Aja, Marlina, Idroes R, Soraya C, Djufri D. Identification of secondary metabolite using phytochemical and infraradiation test on the leaves of Vitex pinnata found in the Seulawah Agam mountain region of Aceh. Res J Pharm Technol, 2019b; 12(11):5247.

Park H-W, Park EH, Yun H-M, Rhim H. Sodium benzoatemediated cytotoxicity in mammalian cells. J Food Biochem, 2011; 35(4):1034-46.

de Paula IMB, Moraes FC, De Souza OV, Yamamoto CH. Development of mouthwash with Rosmarinus officinalis extract. Brazilian J Pharm Sci, 2014; 50(4):851-8.

Pratiwi SUT, Lagendijk EL, de Weert S, Idroes R, Hertiani T, den Hondel C Van. Effect of Cinnamomum burmannii Nees ex Bl. and Massoia aromatica Becc. essential oils on planktonic growth and biofilm formation of Pseudomonas aeruginosa and Staphylococcus aureus in vitro. Int J Appl Res Nat Prod, 2015; 8(2):1-13.

Putri DR, Nanda M, Rizal S, Idroes R, Ismail N. Interpretation of gravity satellite data to delineate structural features connected to geothermal resources at Bur Ni Geureudong geothermal field. IOP Conf Ser Earth Environ Sci, 2019; 364:012003.

Rahmad R, Earlia N, Nabila C, Inayati I, Amin M, Prakoeswa CRS, Khairan K, Idroes R. Antibacterial cream formulation of ethanolic Pliek U extracts and ethanolic residue hexane Pliek U extracts against Staphylococcus aureus. IOP Conf Ser Mater Sci Eng, 2019; 523:012011.

Sampath Kumar N, Balamurugan V. In-vitro antioxidant activity, total phenolic and total flavonoid contents of flower extract of Calotropis gigantea. Res J Phytochem, 2015; 9(3):137-43.

Saquib SA, Alqahtani NA, Ahmad I, Kader MA, Al Shahrani SS, Asiri EA. Evaluation and comparison of antibacterial efficacy of herbal extracts in combination with antibiotics on periodontal pathobionts: an in vitro microbiological study. Antibiotics, 2019; 8(3):1-12.
Seniya C, Singh Trivedia S, Kumar Verma S. Antibacterial efficacy and phytochemical analysis of organic solvent extracts of Calotropis gigantea. J Chem Pharm Res, 2011; 3(6):330-6.

Singh N, Jain NK, Kannojia P, Garud N, Pathak AK, Mehta SC. In vitro antioxidant activity of Calotropis gigantea hydroalcohlic leaves extract. Der Pharm Lett, 2010; 2(3):95-100.

Suhartono E, Setiawan B, Santosa PB, Idroes R, Indrawan MS. Estimation of leaf antioxidant activity using image processing. J Phys Conf Ser, 2019; 1374(1):012057.

Sun D, Xu D, Yang C, Shahzad MB, Sun Z, Xia J, Zhao J, Gu T, Yang K, Wang G. An investigation of the antibacterial ability and cytotoxicity of a novel cu-bearing 317L stainless steel. Sci Rep, 2016; 6(1):1-13.

Tabari K, Hosseinpour S, Pareshet P, Khozestani PK, Rahimi HM. Cytotoxicity of selected nanoparticles on human dental pulp stem cells. Iran Endod J, 2017; 12(2):137-42.

Tallei TE, Linelejan YT, Umboh SD, Adam AA, Muslem, Idroes R. Endophytic bacteria isolated from the leaf of Langusei (Ficus minahassae Tesym. \& De Vr.) and their antibacterial activities. IOP Conf Ser Mater Sci Eng, 2020a; 796:012047.

Tallei TE, Maulana RR, Windah ALL, Wahongan IF, Tumilaar SG, Umar F, Kumaunang M, Sambul AM, Adam AA, Idroes R. The potential use of chitosan deduced from the results of in silico analysis. IOP Conf Ser Earth Environ Sci, 2021a; 667(1):012034.

Tallei TE, Tumilaar SG, Lombogia LT, Adam AA, Sakib SA, Emran TB, Idroes R. Potential of betacyanin as inhibitor of SARS-CoV-2 revealed by molecular docking study. IOP Conf Ser Earth Environ Sci, 2021b; 711(1):012028.

Tallei TE, Tumilaar SG, Niode NJ, Fatimawali F, Kepel BJ, Idroes R, Effendi Y, Sakib SA, Emran TB. Potential of plant bioactive compounds as SARS-CoV-2 main protease (Mpro) and Spike (S) glycoprotein inhibitors: a molecular docking study. Scientifica (Cairo), $2020 \mathrm{~b} ; 6307457$.

Tezara W, Colombo R, Coronel I, Marín O. Water relations and photosynthetic capacity of two species of Calotropis in a tropical semi-arid ecosystem. Ann Bot, 2011; 107(3):397-405.

Tumilaar SG, Fatimawali F, Niode NJ, Effendi Y, Idroes R, Adam AA, Rakib A, Emran TB, Tallei TE. The potential of leaf extract of Pangium edule Reinw as HIV-1 protease inhibitor: a computational biology approach. J Appl Pharm Sci, 2021; 11(1):101-10.

Varposhti M, Entezari F, Feizabadi MM. Synergistic interactions in mixed-species biofilms of pathogenic bacteria from the respiratory tract. Rev Soc Bras Med Trop, 2014; 47(5):649-52.

Wang P, Henning SM, Heber D. Limitations of MTT and MTSbased assays for measurement of antiproliferative activity of green tea polyphenols. PLoS One, 2010; 5(4):e10202.

Wang ZN, Wang MY, Mei WL, Han Z, Dai HF. A new cytotoxic pregnanone from Calotropis gigantea. Molecules, 2008; 13(12):3033-39.

How to cite this article:

Ningsih DS, Idroes R, Bachtiar BM, Khairan K, Tallei TE, Muslem M. In vitro cytotoxicity of ethanolic extract of the leaf of Calotropis gigantea from Ie Jue Geothermal Area, Aceh-Indonesia, and its mouthwash formulation against dental pulp cells. J Appl Pharm Sci, 2022; 12(02):133-143. 